\title{
VZV-associated acute retinal necrosis in a patient with MS treated with natalizumab
}

\author{
Marc Pawlitzki, MD, Jan Teuber, MD, Christin Campe, MD, Markus Wagner, MD, Claudia Schuart, MD, \\ Friedemann Paul, MD, and Daniel Bittner, MD
}

Neurol Neuroimmunol Neuroinflamm 2018;5:e475. doi:10.1212/NXI.0000000000000475

\author{
Correspondence \\ Dr. Pawlitzki \\ marc.pawlitzki@med.ovgu.de
}

Natalizumab (NTZ) was the first approved humanized monoclonal antibody in highly active relapsing remitting MS (RRMS). Because of the mechanism of inhibiting the migration of immune cells through the blood-brain barrier into the CNS, NTZ is associated with an increased risk of progressive multifocal leukoencephalopathy (PML) by the John Cunningham virus (JCV). Infections with other neurotropic viruses are rarely reported. ${ }^{1,2}$ We present a case of rapid retinal necrosis induced by varicella zoster virus (VZV) in a patient with RRMS under long-term NTZ treatment.

\section{Case report}

A 46-year-old Caucasian man diagnosed with RRMS in 2001 was initially treated with interferon beta-1a. After 2 relapses, therapy was switched to NTZ in 2006. Subsequently, the patient presented neither clinical nor radiographic disease activity until January 2018. With the exception of a treatment interruption between 2014 and 2017, he received a total of 127 NTZ infusions. In January 2018, progressive visual loss over 2 days occurred in his left eye. During clinical examination, visual acuity was only 0.2. Apart from a residual subtle paresis of the left leg, no other new neurologic deficits were present. Brain imaging was comparable to a scan acquired 6 months prior, with no signs of new inflammatory lesions. Unexpectedly, ophthalmologic examination showed a retinal vasculitis and focal infiltration in the outer part of the retina (figure $1, \mathrm{~A}-\mathrm{C}$ ). CSF measurement revealed a pleocytosis of 122 cells $/ \mu \mathrm{L}$, positive CSF oligoclonal bands, elevated protein levels of $564 \mathrm{mg} / \mathrm{L}$, albumin quotient (CSF/serum) of 9.1, lactate of $2.0 \mathrm{mmol} / \mathrm{L}$, and isolated VZV intrathecal antibody index of $30.2(<1.5)$. PCR amplification of VZV-DNA was positive in CSF $(8,175$ copies $/ \mathrm{mL})$, whereas other microbiologic CSF and serologic analyses were without pathologic findings. We diagnosed VZVassociated retinal vasculitis and retinitis and initiated IV treatment with acyclovir $(3 \times 900 \mathrm{mg} / \mathrm{d}$ for 16 days). Two days after starting acyclovir treatment, retinal infiltration progressed to acute retinal necrosis. Therapy was escalated using intravitreal ganciclovir injections $(2 \mathrm{mg}$ twice, at days 1 and 4 after progression) (figure $1 \mathrm{~B}$ ) and oral prednisolone $(50 \mathrm{mg} / \mathrm{d}$ ) after negative CSF results for bacterial pathogens. This therapy hindered progression of retinal necrosis, and visual acuity of the left eye improved to 0.5. Fundoscopy showed regressive retinal necrosis with beginning repigmentation of VZV lesions (figure 1C). After 14 days, CSF parameters improved to 47 cells $/ \mu \mathrm{L}$ and 97.5 copies $/ \mathrm{mL}$ of VZV-DNA. Acyclovir was switched to oral application ( $800 \mathrm{mg}$ twice daily) for long-term control of retinal vasculitis. Teriflunomide treatment was started 2 months after the last NTZ infusion to prevent future relapses.

\footnotetext{
From the Department of Neurology (M.P., J.T., C.C., D.B.), Otto-von-Guericke University; Department of Ophthalmology (M.W., C.S.), Otto-von-Guericke University, Magdeburg; Charité-Universitätsmedizin Berlin (F.P.), Corporate Member of Freie Universität Berlin, Humboldt-Universität zu Berlin, and Berlin Institute of Health, NeuroCure Clinical Research Center; Department of Neurology (F.P.), Charité-Universitätsmedizin Berlin, Corporate Member of Freie Universität Berlin, Humboldt-Universität zu Berlin, and Berlin Institute of Health; and Experimental and Clinical Research Center (F.P.), Max Delbrueck Center for Molecular Medicine and Charité - Universitätsmedizin Berlin, Corporate Member of Freie Universität Berlin, Humboldt-Universität zu Berlin, and Berlin Institute of Health, Germany.

Funding information and disclosures are provided at the end of the article. Full disclosure form information provided by the authors is available with the full text of this article at Neurology.org/NN.

The Article Processing Charge was funded by the authors.

Ethical Publication Statement: We confirm that we have read the journal's position on issues involved in ethical publication and affirm that this report is consistent with those guidelines.

This is an open access article distributed under the terms of the Creative Commons Attribution-NonCommercial-NoDerivatives License 4.0 (CC BY-NC-ND), which permits downloading and sharing the work provided it is properly cited. The work cannot be changed in any way or used commercially without permission from the journal.
} 

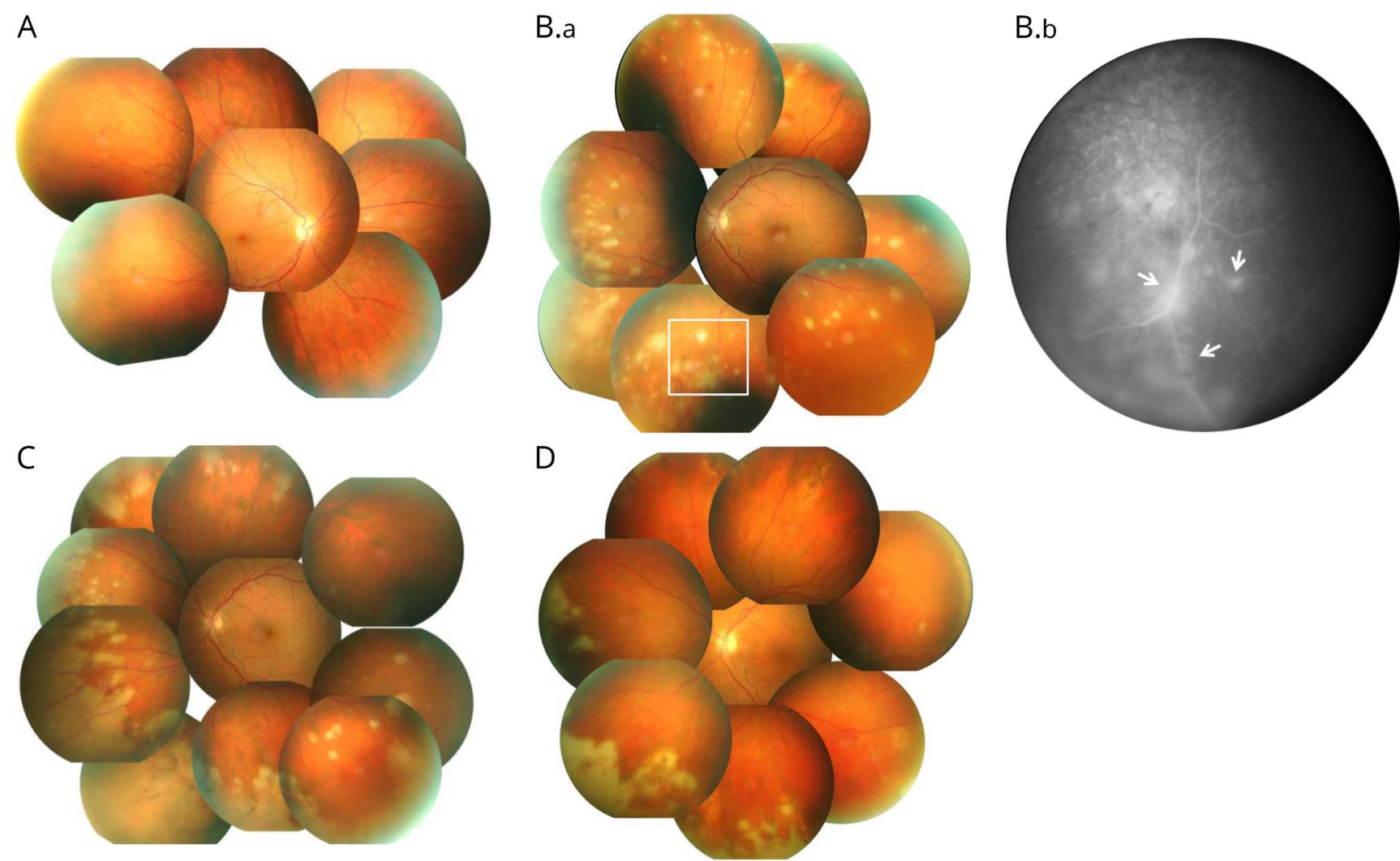

(A) Healthy right eye and (B.a) affected left eye during initial fundoscopy. Multiple focal infiltrations in the peripheral retina are present in the left eye. (B.b) The fluorescent angiography (white box of B.a) illustrates the (peri)-vasculitis as exudates around retinal vessels resulting in white sheathing (arrows). The followup examination (C) after 3 days indicates progression of infiltration due to acute retinal necrosis. Regression of retinal necrosis and beginning of repigmentation of several infiltrates are observed 24 days after initiation of antiviral treatment (D).

\section{Discussion}

Owing to the NTZ-associated PML incidence due to JCV, NTZ-treated RRMS patients are closely monitored by serologic and radiologic means. Other neurotropic virus infections have rarely been identified as critical pathogens in this context, both in clinical trials and in postmarketing observations. ${ }^{3}$ However, several authors have described VZV-induced meningitis ${ }^{2}$ and CNS vasculitis ${ }^{4}$ with associated retinitis in patients treated with $\mathrm{NTZ},{ }^{5}$ which highlights the potential role of other neurotropic virus infections aside from PML.

In contrast to previous reports about VZV reactivation, our patient presented neither with clinical signs of meningeal involvement, nor was he showing any evidence of cerebral vasculitis apart from retinitis, despite the highly elevated CSF cell count. Others have reported patients with vasculitis-mediated ischemic stroke or encephalitis with surprisingly normal ${ }^{5}$ or only slightly elevated CSF cell levels. ${ }^{4}$ It is tempting to speculate that the short time span between clinical onset and treatment initiation (3 days) prevented further cerebral affection. Fortunately, our patient could be saved from developing amaurosis, possibly because of an early and aggressive systemic and additional local antiviral treatment. An early concomitant drug therapy should therefore be considered in future cases, showing progression to retinal necrosis after initiation of IV antiviral treatment.

Moreover, without close ophthalmologic examination, the isolated vision loss could have easily been misdiagnosed as an optic neuritis, a typical syndrome in patients with RRMS. High doses of steroids are commonly indicated in this scenario ${ }^{6}$ with possible detrimental consequences to the patient's eye sight.

Of interest, NTZ-treated MS patients have a significant increase in serologic anti-VZV-IgG levels compared with healthy controls, indicating a tendency toward a subclinical VZV reactivation before clinical manifestation. ${ }^{7}$ Consequently, this could imply an increased risk of VZV infections similar to the elevated risk of PML under long-term NTZ treatment.

In addition to the diagnosis of MS relapse or PML, physicians should consider other opportunistic infections when new neurologic deficits present under long-term NTZ treatment. 


\section{Author contributions}

Marc Pawlitzki has access to all the data and takes responsibility for the data, accuracy of the data analysis and interpretation of the data, and drafting the manuscript for intellectual content. Jan Teuber: design and conceptualization of the case and revising the manuscript for intellectual content. Christin Campe: design and conceptualization of the case and revising the manuscript for intellectual content and language improvement. Markus Wagner: design and conceptualization of the study and revising the manuscript for intellectual content. Claudia Schuart: design and conceptualization of the case and revising the manuscript for intellectual content. Friedemann Paul: critical revision of the manuscript for important intellectual content. Daniel Bittner: study supervision.

\section{Study funding}

No targeted funding reported.

\section{Disclosure}

M. Pawlitzki received speaker honoraria from Roche, Genzyme, and Novartis and travel/accommodation/meeting expenses from Novartis, Biogen Idec, Genzyme, and Merck Serono. J. Teuber received research support from the German National Academic Foundation. C. Campe, M. Wagner, and C. Schuart report no disclosures. F. Paul has received honoraria and research support from Alexion, Bayer, Biogen, Chugai, Merck Serono, Novartis, Genyzme, MedImmune, Shire, Teva, and Sanofi/Aventis; serves on the scientific advisory boards of
Alexion, MedImmune, and Novartis; served as an academic editor of PLoS ONE and an associate editor of Neurology: Neuroimmunology \& Neuroinflammation; consulted for Sanofi Genzyme, BiogenIdec, MedImmune, Shire, and Alexion; and has received funding from Deutsche Forschungsgemeinschaft (DFG Exc 257), Bundesministerium für Bildung und Forschung (Competence Network Multiple Sclerosis), Guthy Jackson Charitable Foundation, EU Framework Program 7, National Multiple Sclerosis Society of the USA, Arthur Arnstein Stiftung Berlin, and Arthur Arnstein Foundation Berlin. D. Bittner has received honoraria from Bristol-Myers Squibb. Full disclosure form information provided by the authors is available with the full text of this article at Neurology.org/NN.

Received March 26, 2018. Accepted in final form May 30, 2018.

\section{References}

1. Schippling S, Kempf C, Büchele F, et al.JC virus granule cell neuronopathy and GCNIRIS under natalizumab treatment. Ann Neurol 2013;74:622-626.

2. Fine AJ, Sorbello A, Kortepeter C, Scarazzini L. Central nervous system herpes simplex and varicella zoster virus infections in natalizumab-treated patients. Clin Infect Dis 2013;57:849-852.

3. Williamson EML, Berger JR. Central nervous system infections with immunomodulatory therapies. Continuum (Minneap Minn) 2015;21:1577-1598.

4. Mulero P, Auger C, Parolin L, et al. Varicella-zoster meningovasculitis in a multiple sclerosis patient treated with natalizumab. Mult Scler 2018;24:358-360.

5. Kobeleva X, Wegner F, Brunotte I, Dadak M, Dengler R, Stangel M. Varicella zosterassociated retinal and central nervous system vasculitis in a patient with multiple sclerosis treated with natalizumab. J Neuroinflammation 2014;11:19.

6. Galetta SL, Villoslada P, Levin N, et al. Acute optic neuritis: unmet clinical needs and model for new therapies. Neurol Neuroimmunol Neuroinflamm 2015;2:e135. doi: 10. 1212/NXI.0000000000000135.

7. Kohlmann R, Salmen A, Chan A, et al. Serological evidence of increased susceptibility to varicella-zoster virus reactivation or reinfection in natalizumab-treated patients with multiple sclerosis. Mult Scler 2015;21:1823-1832. 


\title{
Neurology $^{\odot}$ \\ Neuroimmunology \& Neuroinflammation
}

\author{
VZV-associated acute retinal necrosis in a patient with MS treated with natalizumab \\ Marc Pawlitzki, Jan Teuber, Christin Campe, et al. \\ Neurol Neuroimmunol Neuroinflamm 2018;5; \\ DOI 10.1212/NXI.0000000000000475
}

This information is current as of July 9, 2018

\begin{abstract}
Updated Information \&
Services

including high resolution figures, can be found at:

http://nn.neurology.org/content/5/5/e475.full.html

References

This article cites 7 articles, 0 of which you can access for free at: http://nn.neurology.org/content/5/5/e475.full.html\#\#ref-list-1

Subspecialty Collections

This article, along with others on similar topics, appears in the

following collection(s):

All Neuro-ophthalmology

http://nn.neurology.org//cgi/collection/all_neuroophthalmology

Multiple sclerosis

http://nn.neurology.org//cgi/collection/multiple_sclerosis

Retina

http://nn.neurology.org//cgi/collection/retina

Viral infections

http://nn.neurology.org//cgi/collection/viral_infections

Visual loss

http://nn.neurology.org//cgi/collection/visual_loss

Permissions \& Licensing

Information about reproducing this article in parts (figures,tables) or in its entirety can be found online at:

http://nn.neurology.org/misc/about.xhtml\#permissions

Reprints

Information about ordering reprints can be found online:

http://nn.neurology.org/misc/addir.xhtml\#reprintsus

Neurol Neuroimmunol Neuroinflamm is an official journal of the American Academy of Neurology.

Published since April 2014, it is an open-access, online-only, continuous publication journal. Copyright

Copyright (C) 2018 The Author(s). Published by Wolters Kluwer Health, Inc. on behalf of the American

Academy of Neurology.. All rights reserved. Online ISSN: 2332-7812.
\end{abstract}

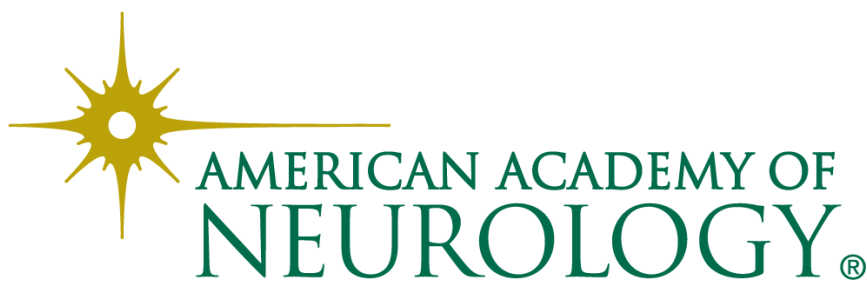

